\title{
Effects of Accounting Information on Excess Return Using Fama and French Three-factor Model in Order to Examine Capital Market Reaction Due to Dividend Announcement
}

\author{
Diaraya1', Gagaring Pagalung², Abdul Hamid Habbe², R.A. Damayanti² \\ ${ }^{1}$ Faculty of Mathematics and Natural Sciences, Hasanuddin University, Indonesia \\ ${ }^{2}$ Faculty of Economics and Business, Hasanuddin University, Indonesia
}

\begin{abstract}
This paper discussed the effects of accounting information on the excess return of shariah stocks and conventional stocks using Fama and French Three Factor Model, and examined the reaction of the capital markets as a result of the dividend announcement.

The results and data analysis had yielded 8 stock portfolios. It can be concluded that the AER variable movements had an immediate reaction to the movement, meaning that the dividend announcement brought the content of the information to the capital markets or it can be said that the Indonesian capital market conditions have started heading to a semi-strong form.
\end{abstract}

Key words: Fama and french three factor model; Accounting information; Dividend; Excess return; Market efficiency

\section{Introduction}

The information contained in financial report of the company plays an important role in the capital markets, both for the individual investor and for the overall market. Accounting information as a scientific process is about provision of financial information needed to take decision particularly in respect of acquisition and use of scarce corporate resources as well as the elimination of wastes in the wealth creation chain to maximize profit (Agbaje, Busari and Adeboye, 2014). In recent years, accounting information received a lot of attention, it facilities managers to

\footnotetext{
*Corresponding author's Gagaring Pagalung, gpagalung@yahoo.com ISSN: 2549-3221 (Print) 2549-323X (Online) DOI: http://doi.org/10.26487/hebr.v1i1.1160
} 
take appropriate actions related to issues in organization, if accounting information system output is not accurate management will take wrong decisions, moreover, it considered competitive advantage for organization with well design accounting information system. Failure to implement well accounting information system will have adverse effects on organization success (Noori, Jalili and Nia, 2014). The importance of accounting information for the efficiency of the stock price setting process (Novak, 2008). Rationality in financial markets implies that investors correctly use all available information in establishing security prices. A natural consequence of this definition is that researchers concernet with how stock returns are generated must first consider how market participants determine and assimilate the relevant in their decision making, where the costs of producing and procesing information are explicitly recognized. The efficient market hypothesis (EMH) claims that the price of a security at any point is a noisy estimate of the present value of the certainly equivalents of its risky future cash flows (Brown, Harlow and Tinic, 1988). The Simple model of continuous trading demonstrates how the liquidity characteristics of an efficient market can be derived from underlying information asymmetries in a dynamic trading environment which captures some relevant features of trading in organized exchanges (Kyle, 1985). Accounting information reduces information asymmetries, which lead to adverse selection in transaction activities in the stock market (Apergis, et.all., 2011). In companies that go public, the value of the company is viewed from its stock price. The stock price reflects the value of companies in the capital market in an efficient situation. An efficient market may indicate the stock prices that fully reflect the provided information, where the information may include company annual reports, dividend distribution, capital market analysts' reports, etc. Efficient capital markets make stock prices tend to be reasonable and truly reflect the value of the stocks in question until there are no longer overvalued or undervalued stockprices (Binsar and Sumiyana, 2008).

On the other hand, stocks are investment instruments selected by many investors because the stock is able to provide an attractive level of profits. Stock can be defined as a sign of ownership of a person or party (entity) within a corporation or limited liability company. With the inclusion of capital, then that party has a claim on the company's revenue, a claim on the company's assets, and is entitled to attend the General Meeting of Shareholders (Indonesia Stock Exchange: $\underline{w w w .}$ idx.co.id, 2016). Islamic stocks are stocks that comply with the Islamic law (Shari'ah) and are sometimes referred to as Shari'ah-compliant stocks. Stocks that do not comply with the Islamic law are referred to as non-Islamic stocks. Further, the combination of Islamic and non-Islamic stocks is referred to as the market or as conventional stocks. (Akhtar and Jahromi, 2015). ${ }^{1}$

Shari'ah stock index is issued by the shari'ah Capital Market Institutions, in which the index is based on all stocks listed in the shari'ah Capital Markets that have previously been selected by the National Shari'ah Board, whereas conventional stock index are all stocks listed on the Indonesia Stock Exchange.

Sularso (2003) explained that based on the results of statistical tests, we can conclude that the effect of dividend announcements on stock price changes is indicated by the acquired of abnormal return around the date of

1 Stocks consist of two types, namely shari'ah/islamic stocks and conventional stocks. 
the ex-dividend date. Abnormal return occurred because investors do not always get the information simultaneously. If an investor gets information faster than the others then such investor will have an opportunity to get abnormal return, which is greater than the other investors. One of the information receiving the most responses from the public was the dividend announcement. Information from the announcement of the amount of positive dividend tends to be considered as good news by the market, whereas the announcement of negative dividend tends to be considered as a bad news. Dividend policy is relevant to investors because an investor's declared dividends have a dual function, constituting both the investor's regular income and serving as a principal factor in a firm's valuation (Asiri, 2014).

Market's negative reaction is reflected in the negative excess return which has been proved by research conducted by Mederios and Matsumoto (2006) while the positive excess return is occurred if the returns obtained greater than what they have been expected or calculated. Information relevant to decision subject is among the factors effective on decision making. If the required information distributes asymmetrically between the people (Information communication is done unequally between people) can lead to different results. So, before the information is important for decision maker, information communication quality is evaluated accurately (Darabi, 2012). Announcement of dividend payments may carry some information for the market and stock prices may be adjusted accordingly (Uddin and Osman, 2008). The content of the information is also useful for assessing accounting profit figures (Ball and Brown, 1968). Investors believe that the announcement of the dividend may provide benefits both for investors who wish to gain profit in the long term and the investors who just want to gain profit in a shortterm. Hermuningsih and Wardani (2009) explained that the information is considered informative if it is able to change the trust of the decision-makers. The existence of a new information will form a new confidence among investors. The new confidence will change the supply and demand of securities. If the capital market is efficient then changes in supply and demand might be enable in changing the price of such securities. In addition, information also affecting a decision to buy stocks is the dividend announcement.

Referring to Jogiyanto (2012) generally, the period also involves the day before the event date in order to determine whether there is leakage of information, for instance whether the market has heard the information before the information itself is announced. Meanwhile, according to Samsul (2010) abnormal return or excess return represents the difference between the actual return with the expected return which may occurred prior to publication of the official information or when an leakage of information occured after the publication of official information. Events of studies have two categories; the first category is used to examine the information content of an event. If an event contains information then the market will respond indicated by the abnormal return. The second category of the study is to examine the events of the efficient market, which is a continuation of the testing of information content. If the testing of the information content only testing abnormal return as the reaction of the market, hence the efficient market testing will be followed by testing the speed of the market reaction (Jogiyanto, 2015) information content can be either good news or bad news (Tandelilin, 2010). Efficient capital 
markets are defined as capital market having securities prices reflecting all relevant information (Husnan and Pudjiastuti, 2012) and in order to determine the efficiency of the market, it is tested through looking at the abnormal return that occured (Jogiyanto, 2003). To enable the efficient capital market, it is important to conduct voluntary corporate disclosure of information by management (Healy and Palepu, 2001). Despite the fact, voluntary corporate disclosure of profit information is rare (Skinner, 1994).

\section{Literature Study}

Our results indicate that cash dividend announcements do convey information to the market. That is, firms announcing an increase in their dividends experience a significant positive price reaction, and firms announcing dividend decreases experience a significant decline in stock prices. Firms that have no change in their dividends report insignificantly negative average abnormal returns (AlYahyaee, Pham and Walter, 2011). In accordance to Fama and French (1996) factors affecting stock returns other than market factors are and factor of company size and factor of book-tomarket equity. Fama and French in (1992) stated that beta market is not able to explain stock returns, otherwise the size of the company and the book-tomarket equity are able to explain. Fama and French (1993) use three factors that explain the stock portofolio return made in accordance with the company size and book-to-market equity. Fama and French (1998) also stated that companies with the high book-to-market equity provide higher return than the low bookto-market equity in 12 stock markets, and companies with small stock provide higher return than the large stock in 11 stock markets. A three factor asset pricing model that includes a market factor and risk factors related to size and $B E / M E^{2}$ seems to capture the cross section of average returns on US stocks (Fama and French, 1995). Fama and French (1993) added that there is a negative relations between $S M B^{3}$ and returns. This might occur due to the increase of excess returns on small companies, which almost doubled compare to the returns of large companies. Excess return stock provides greater return compare to growth in line with Fama and French (1992) that $H M L^{4}$ holds a stronger role of the size factor. If I form portfolios according to the dividend yield, for the same period of time and for the same market, I can construct four different portfolios: those which got dividend yield equal to zero, then another portfolio built with the $30 \%$ of firms which had a low dividend yield, the third portfolio was constructed with the $40 \%$ of firms which got medium dividend yield and the last portfolio was formed using the $30 \%$ of firms with high dividend yield (Blanco, 2012).

Investment in Islamic stock index is realized with the sharia stock index is currently represented by the establishment

$2 B E / M E$ is The book-to-market ratio is a ratio used to find the value of a company by comparing the book value of a firm to its market value. Book value is calculated by looking at the firm's historical cost, or accounting value. Market value is determined in the stock market through its market capitalization (www. Investopedia .com).

3 Small minus big $(S M B)$ is one of three factors in the Fama and French stock pricing model. $S M B$ accounts for the spread in returns between small and large-sized firms, which is based on the company's market capitalization (www. Investopedia .com)

4 High minus low $(H M L)$ is one of three factors in the Fama and French asset pricing model. $H M L$ accounts for the spread in returns between value and growth stocks and argues that companies with high book-to-market ratios, also known as value stocks, outperform those with lower bookto-market values, known as growth stocks (www. Investopedia .com) 
of the Jakarta Islamic Index $(J I I)^{5}$ . Companies that can be incorporated in the Jakarta Islamic Index is a company that has to meet several requirements including the company doesn't run a business that is contrary to Islamic principles and not conventional financial institutions are implementing the system of usury (Fitri, Hosen and Muhari, 2016). Based on the results of research and discussion undertaken by Yulia and Artini (2015) regarding the analysis of market reaction to the announcement of cum dividend on the company listed in the Jakarta IslamicIndex(JII), theconclusion that can be drawn is that there is market reaction shown significantly by $A E R^{6}$ around the cum dividen announcement date. $A E R$ with negative value indicates that there is significant market reaction to the announcement of cum dividend responded negatively by investors. Result of research from Hidayati (2014) showed that there was no significant difference between the abnormal return before and after the dividend announcement on the Compass-10o Index. Similarly, the result of research from (Ratnawati, Sumiyati and Triyuwono, 2009) stated that overall there are no significant differences between stock returns on the period before and during the announcement of the dividend, either on period of 5 days or on period of 10 days around the announcement of the dividend.

Result of research from (Kholisoh and Suryawan, 2007) concluded that although in test hypotheses there is no difference on the average of abnormal return before and after the dividend announcement. However based on the graphic images, there is a decline in abnormal return on day $t+1$. From the description of the graph can be concluded that there are

\footnotetext{
5 The Jakarta Islamic Index (JII) is a stock market index established on July 3, 2000 on the Indonesia Stock Exchange.

$6 A E R$ is average excess return for dependent vari-
} able. significant changes in stock prices before and after the announcement of dividend distribution. Prayitno (2012) explained that the results of this study indicate that market participants react quickly on the dividend distribution announcement after a long absence of dividend. The presence of information content from the announcement of dividend distribution after a long absence of dividend by the company in the period 2004-2009 shows that there had been a possibility of asymmetric information in the capital market. Besides to determine whether there is information content, calculation of the abnormal returns is also intended to determine the level of efficiency of capital markets by looking at the speed of market participants in response to information received, thus it can be concluded that the Indonesian Capital Market in the period 2004-2009 had efficiently formed the half strong information, as an information received quick reaction from traders or investors. Results of research (Gantyowati, Evi and Sulistyani, 2008) stated that announcement of the dividend on the company entering CGPI received reaction from the market indicated by the significant Security Return Variability (SRV) around the date of the dividend announcement. (Hermuningsih and Wardani, 2009), explained the results of hypothesis testing using paired of sample $t$-test and one sample of $t$-test with a significant level of 0.05 . The results showed that the market reacted strongly to the announcement of the rights issue and the announcement of dividend. According to (Sudira and Ketut, 2014), it can be concluded that there was no significant difference between the abnormal return before and after the announcement of cash dividends. It meant that the information of cash dividend announcement on the companies listed on the Indonesia Stock Exchange in 2009-2012 did not affect 
investors'decisiontoinvest. Similarlywith the results of the research from (Binsar and Sumiyana, 2008) stated that there was indication that profit information received by Bapepam- $L K$ become invalid due to the possibility that profit information has been leaked in advance before being received by Bapepam-LK. Therefore during the profit announcement, investors and other market participants had not given immediate respond around the profit announcement date. In other words, investors assume that the profit information was stale.

In this study it has observed the response and nature of the stock market on the release of companies annual earnings and dividends, listed on Karachi Stock Market. In particular, this study assesses the information, content and usability earnings releases to investors in the KSE, by measuring the rate of market reaction to corporate earnings information disclosure. According to the evidence documented in the existing literature, support the hypothesis that the information content obtained (Manzoor, 2015). Overall, the results indicate that there is a considerable informational content of dividend announcements in Colombo Stock Exchange. The investors consider dividend announcements as favorable news. Further, Colombo Stock Exchange reacts in the same way to dividend increase, dividend decreases and no change in dividend. In addition, the results in this study supported the semi-strong form of the efficient capital market hypothesis; that is, on the average, the stock market adjusts in an efficient manner to new dividend information (Dharmarathne, 2013).

\section{Hypotheses}

\section{Earning Per Share (EPS)}

Earning Per Share (EPS) is the first fundamental component that must be considered in analysing companies. EPS Information of a company shows the company's net profit, which is ready to be distributed to all shareholders of the company. The amount of a company's EPS can be determined from the company's financial reports (Tandelilin, 2010).

From the previous description, hypothesis that can be concluded is that: $\mathrm{H}_{1}$ : Earning Per Share (EPS) affected the stock returns in companies listed on the Indonesia Stock Exchange

\section{Debt to Equity Ratio (DER)}

Debt to Equity Ratio (DER) is the ratio of total debt to total equity share holders of the company. Total debt is the total liabilities, while total shareholders' equity is the total equity of capital owned by the company. This ratio shows the composition of the capital structure of the total debt towards total capital owned by the company. According to Ang (1997), the higher the ratio of Debt to Equity Ratio (DER), the smaller the rate of return.

From the previous description, hypothesis that can be concluded is that: $\mathrm{H}_{2}$ : Debt to Equity Ratio (DER) affected the stock returns in companies listed on the Indonesia Stock Exchange

\section{Return on Assets (ROA)}

Return on Assets (ROA) is one of the most fundamental profitability ratios used to predict the price or stock returns of the public companies. $R O A$ is used to measure the effectiveness of the company in generating profits by utilizing its assets. Ulupui (2005) stated that the higher the $R O A$, the more effective companies in utilizing its assets in order to generate a net profit after tax. Thus, the higher the $R O A$, the more effective the company's performance is. 
From the previous description, hypothesis that can be concluded is that: $\mathrm{H}_{3}$ : Return on assets (ROA) affected the stock returns in companies listed on the Indonesia Stock Exchange

\section{Return on Equity (ROE)}

Return on Equity $(R O E)$ is an essential ratio for the owners and shareholders, because such ratio indicates the company's ability to manage capital from shareholders in order to obtain net income.

The ratio of profitability measured by Return on Equity ( $R O E$ ), which is a ratio, measures the ability of the existing total equity in the company, hence $R O E$ can often be equated with its own capital profitability. The high $R O E$ shows the improvement of the company's ability and leads to the high stock price. If the stock price goes up causing the increasing of stock returns, it allows $R O E$ to have an effect on stock returns (Sujana and Yuliantari, 2014).

From the previous description, hypotheses that can be concluded are:

$\mathrm{H}_{4}$ : Return on Equity (ROE) affected the stock returns in companies listed on the Indonesia Stock Exchange

$\mathrm{H}_{5}: R O A, E P S, D E R$ and $R O E$ collectively affected the stock returns on companies listed in the Indonesia Stock Exchange

\section{Fama and French Three Factor Model}

Fama and French (1998) suggests that companies with high book-to-market equity provide higher returns than the low book-to-market equity in 12 capital markets and companies with small stocks provide higher returns than large stocks in 11 capital markets (Damar and Suherman, 2007). Factors proposed Fama and French as variables affecting returns portfolio are the book-to-market and company size (size). Within Fama and French Three Factor Model are $H M L$ factor and $S M B$ obtained and groups of returns stocks that have a high $(H)$, medium $(M)$ and low $(L)$ book-to-market and the grouping of stock returns that have a small $(S)$ and large $(B)$ company size (Susanti, 2013).

From the previous description, hypotheses that can be concluded are:

$\mathrm{H}_{6}$ : Market premium (beta coefficient) influenced the excess return

$\mathrm{H}_{7}$ : Small minus big influenced the excess return

$\mathrm{H}_{8}$ : High minus low influenced the excess return

\section{Dividend Payout}

Dividend payout is one thing awaited by the shareholders. Dividend payout may performed quarterly or annually, depending on the policy determined by the respective companies (Sularso, 2003). If a company issues stock, the issuer does not have a definite obligation to pay dividends, because the dividend distribution is determined based on the level of corporate profits and shareholder approval. Dividend distribution schedule has become essential for investors, because the schedule of dividend distribution affecting the stock price in the stock exchange (Kholisoh and Suryawan, 2007).

From the previous description, hypotheses that can be concluded are:

$\mathrm{H}_{9}$ : There was a difference of return before and after the announcement of positive cash dividend on conventional stock within period of 2014 in the Indonesia Stock Exchange

$\mathrm{H}_{10}$ : There was a difference of return before and after the announcement of negative cash dividend on conventional stock within period of 2014 in the Indonesia Stock Exchange 
$\mathrm{H}_{11}$ : There was a difference of return before and after the announcement of positive cash dividend on conventional stock within period of 2015 in the Indonesia Stock Exchange

$\mathrm{H}_{12}$ : There was a difference of return before and after the announcement of negative cash dividend on conventional stock within period of 2014 in the Indonesia Stock Exchange

$\mathrm{H}_{13}$ : There was a difference of return before and after the announcement of positive cash dividend on shari'ah stock within period of 2014 in the Indonesia Stock Exchange

$\mathrm{H}_{14}$ : There was a difference of return before and after the announcement of negative cash dividend on shari'ah stock within period of 2014 in the Indonesia Stock Exchange

$\mathrm{H}_{15}$ : There was a difference of return before and after the announcement of positive cash dividend on shari'ah stock within period of 2015 in the Indonesia Stock Exchange

$\mathrm{H}_{16}$ : There was a difference of return before and after the announcement of negative cash dividend on shari'ah stock within period of 2014 in the Indonesia Stock Exchange

\section{Research Methods}

Research Design

The research design for Asset Pricing Model was using Fama and French Three-Factor Model.

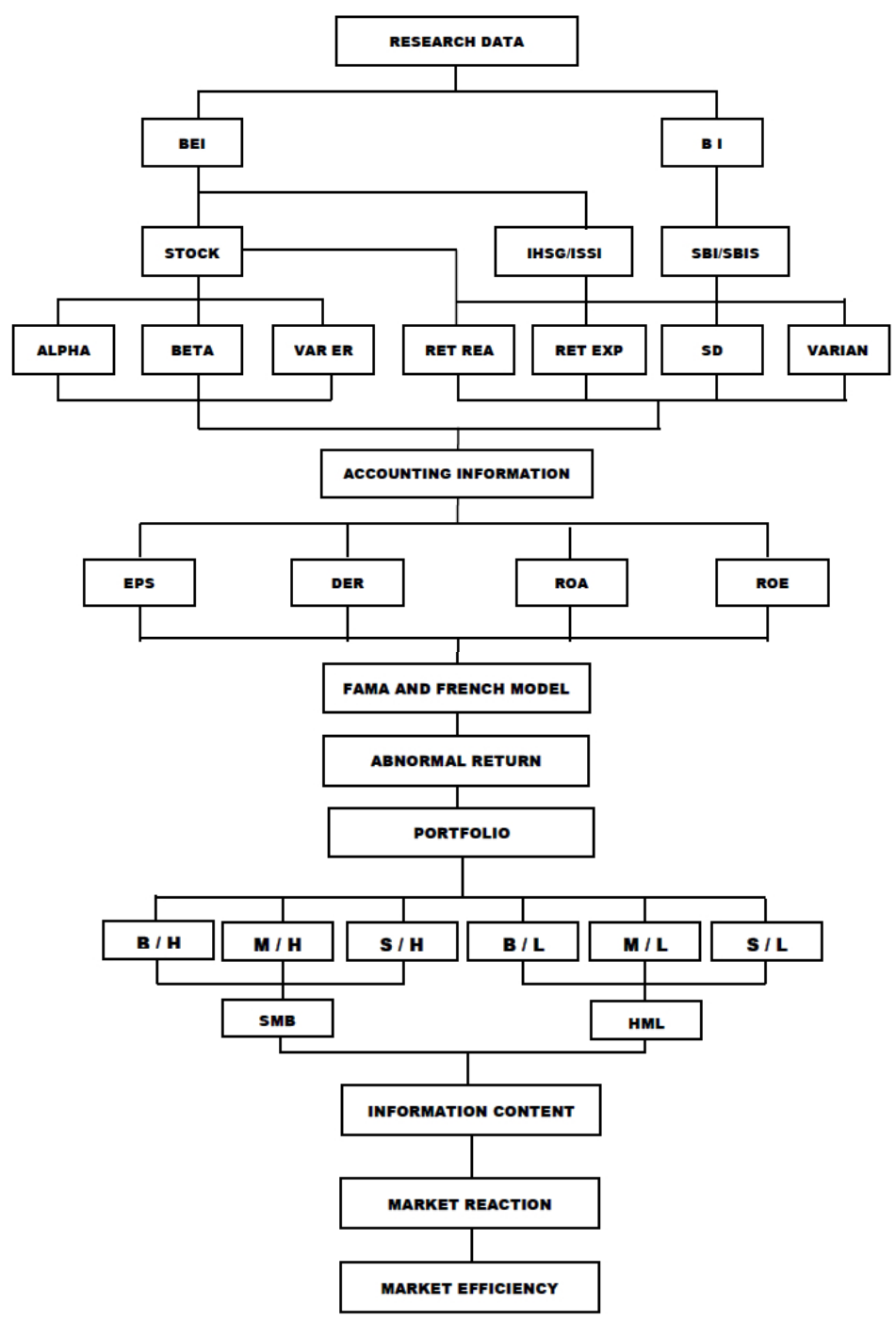


Where :

\begin{tabular}{|c|c|}
\hline$B I$ & : Bank of Indonesia \\
\hline$B E I$ & : Indonesia Stock Exchange \\
\hline IHSG & : Composite stock price index \\
\hline ISSI & $\begin{array}{l}\text { : Indonesia Shari'ah Stock } \\
\text { Index }\end{array}$ \\
\hline$S B I$ & : Bank Indonesia Certificates \\
\hline SBIS & $\begin{array}{l}\text { Bank Indonesia Shari'ah } \\
\text { Certificates }\end{array}$ \\
\hline ALPHA & : Alpha \\
\hline BETA & : Beta \\
\hline$V A R E R$ & : Varian Error \\
\hline RET REA & : Return Realitation \\
\hline RET EXP & : Return Expectation \\
\hline$S D$ & : Standart Deviation \\
\hline VARIAN & : Varian \\
\hline$E P S$ & Earning Per Share \\
\hline$D E R$ & : Debt to Equity Ratio \\
\hline$R O A$ & : Return on Asset \\
\hline$R O E$ & : Return on Equity \\
\hline$B / H$ & : Big / High \\
\hline$M / H$ & : Median / High \\
\hline$S / H$ & : Small / High \\
\hline$B / L$ & : Big / Low \\
\hline$M / L$ & : Median / Low \\
\hline$S / L$ & : Small / Low \\
\hline$S M B$ & : Small Minus Big \\
\hline$H M L$ & : High Minus Low \\
\hline
\end{tabular}

$S M B=\frac{\left(\frac{S}{L}+\frac{S}{M}+\frac{S}{H}\right)-\left(\frac{B}{L}+\frac{B}{M}+\frac{B}{H}\right)}{3}$ and $H M L=\frac{\left(\frac{S}{H}+\frac{B}{H}\right)-\left(\frac{S}{L}+\frac{B}{L}\right)}{2}$

\section{Research Site}

The research was carried out in all companies listed on the Indonesia Stock Exchange period of 2014 - 2015 and conducting the dividend announcement.

\section{Population, Sample and Sampling Techniques}

The populations in this research involve all companies listed in Indonesia Stock Exchange in accordance with publications of Indonesian Stock Exchange (IDX), Indonesian Central Securities Depository (KSEI), Bank Indonesia, Yahoo Finance and the
Financial Services Authority (OJK).

The sampling technique in this study was using a non-probability sampling technique which is purposive sampling, data selection based on specific criteria or judgment sampling. It was a sampling technique performed with certain considerations, such as characters samples that are already known. Testing of samples of the company's stocks, both conventional stock and shari'ah stock in period of 2014 - 2015, was conducted using panel data regression analysis using SPSS software version 23. In addition, a study was also conducted to test the information content of an announcement, in order to see the market reaction of an announcement.

\section{Types and Sources of Data}

This research used panel data. While the types of data used in this research were secondary data, obtained from:

The companies listed in Indonesia Stock Exchange in period of 2014 2015 which have complete and reliable financial data.

Companies whose shares are actively traded on the Indonesia Stock Exchange in period of 2014 - 2015.

The companies announced the cash dividend and the announcement dates were known during the period of 2014 2015 .

\section{Data Collection Methods}

The data used in this research were secondary data including financial data and ratios (EPS, DER, ROA and ROE), announced the cash dividend and the announcement date were known, daily data such as stock prices of companies listed on the Indonesia Stock Exchange that were sampled, Composite stock price index (IHSG), Indonesia Shari'ah Stock Index (ISSI), Bank Indonesia Certificates $(S B I)$ and Bank Indonesia 
Shari'ah Certificates $(S B I S)$.

\section{Variable}

Examinations of hypotheses on the relation of variable earning per share $(E P S)$, debt to equity ratio (DER), return on assets $(R O A)$ and return on equity $(R O E)$ toward return stock in this research, were made a multiple regression equation as follow:

$Y=\alpha+\beta_{1} X_{1}+\beta_{2} X_{2}+\beta_{3} X_{3}+\beta_{4} X_{4}+\varepsilon$

where :

$Y \quad$ : Excess Return Fama and French Three Factor Model

$\alpha \quad$ : constants

$\beta_{1}, \beta_{2}, \beta_{3}, \beta_{4}$ : regression coefficients

$X_{1} \quad: E P S$

$X_{2} \quad: D E R$

$X_{3}: R O A$

$X_{4}^{3} \quad: R O E$

$\varepsilon \quad$ : residual

Excess Return Fama and French Three Factor Model is defined as (Fama and French, 1995):

$\operatorname{Ri}(\mathrm{t})-\operatorname{Rf}(\mathrm{t})=\alpha+\beta[\operatorname{Rm}(\mathrm{t})-$

$\mathrm{Rf}(\mathrm{t})]+\mathrm{s} S M B(\mathrm{t})+\mathrm{h} H M L(\mathrm{t})+\mathrm{e}(\mathrm{t})$

Information :

$\operatorname{Ri}(t)-R f(t)$ : average of excess return minus risk free rate on the t period

$\mathrm{Rm}(\mathrm{t})-\mathrm{Rf}(\mathrm{t})$ : excess return market portofolio on the t period

$S M B(\mathrm{t}) \quad$ : return portofolio $S M B$ on the $t$ period

$H M L(\mathrm{t}) \quad$ : return portofolio $H M L$ on the $t$ period

$\beta, \mathrm{s}, \mathrm{h} \quad$ : regression coefficients

a $\quad$ : constants

e(t) $\quad$ : random error

\section{Results}

\section{Description of Research Samples}

The populations in this study were all stocks in companies listed on the Indonesia Stock Exchange in 2014 -
2015 which had also conducted dividend announcement. The characteristic of the research object is return measured through excess return over the observation period of 111 days consist of 11 days windows observation period and 100 days estimation observation period. The sampling was conducted using purposive sampling during period of 2014 - 2015 by panel data regression analysis using SPSS software version 23. The number of samples that meet the sample selection criteria during the period 2014-2015 are 106 companies announcing cash dividend, which consists of 70 shari'ah companies and 36 conventional companies. The object of the research had been representing all sectors of industry in the Indonesia Stock Exchange. Classification sample based on the industrial sector can be seen in Table 1.

\section{Descriptive Statistics Analysis}

Before testing the hypotheses, descriptive statistical analysis of the data sample was conducted in order to determine the characteristics of each variable. Descriptive statistical analysis is a data analysis technique used to provide an overview of the sample characteristics. Characteristics of the sample described in the form of beta value and excess return can be seen in Table 2a until Table 2.d. Characteristics of the sample of the company's stock portfolio can be seen in Table $3 a$ until Table $3 \mathrm{~h}$, and data recapitulation of Fama and French Three Factor Model can be seen in Table 4.

\section{Classical Assumption Test}

In the classical assumption test will be conducted normality test, multicollinearity test, heterocedasticity test and autocorrelation test. Whereas the $F$ test and $t$ test will be carried out during the analysis of the results of hypothesis 
testing.

The formula for Testing the effect of the dividend announcement on the excess return measured by the dependent variable average excess return using the Fama and French Three Factor Model on company stock announcing the cash dividend in the period of $2014-2015$ is:

$$
\begin{aligned}
& A E R \_F F 1415=\beta_{\mathrm{o}}+\beta_{1} E P S+\beta_{2} D E R+ \\
& \beta_{3} R O A+\beta_{4} R O E+\varepsilon_{\mathrm{i}}
\end{aligned}
$$

where :

$A E R \_F F 1415$ : average excess return using Fama and French Three Factor Model on company stock announcing the cash dividend in the period of 2014 - 2015

EPS : earning per share of the company

$D E R$ : debt to equity ratio of the company

$R O A$ : return on asset of the company

$R O E$ : return on equity of the company

$\beta_{\mathrm{o}}, \beta_{1}, \beta_{2}, \beta_{3,} \beta_{4}$ regression coefficients

$\varepsilon_{\mathrm{i}} \quad$ : residual

\section{Normality Test}

Normality test was intended to examine whether the value of the standardized residuals in regression models had been normal distributed or not. The residual value was classified to be normally distributed if the most of the residual value of the standardized approached the average value.

The results of the analysis of the data in Table 5 showed that the coefficient of skewness $=0.088$ and coefficient of kurtosis $=-0.404$. The next step was standardizing the calculation as follows:

zskew $==0.453008$ and zkurt

$$
\begin{aligned}
& \text { zskew }=\frac{\mathrm{S}-0}{\sqrt{6 / \mathrm{N}}}=\frac{0.088}{\sqrt{6 / 636}}=0.453008 \\
& \text { zkurt }=\frac{\mathrm{K}-0}{\sqrt{24 / \mathrm{N}}}=\frac{-0.404}{\sqrt{24 / 636}}=-2.07972
\end{aligned}
$$

$==-2.07972$

In conclusion, since the standardized value of skewness (zskew) $=0.453008$ and standardized value of kurtosis (zkurt) $=-2.07972$ less than 2.58 , consequently with a 0.05 percent of tolerance level, the value of the standardized residuals was normally distributed.

\section{Multicolinearity Test}

Multicoliniarity test can be done by looking at the value of Tolerance and Variance Inflation Factor (VIF) of each independent variable on the dependent variable. If the $V I F$ value was less than 10, then the model would be declared to have no multicollinearity symptoms.

The results of the data analysis in Table 6 showed that the VIF was less than 10 , so it can be concluded there was no multicollinearity symptoms.

\section{Heteroscedastity Test}

Heteroscedasticity test is carried out when there is a variant of the variables in the regression model which is not the same (constant). However, if the variance in regression models have the same value, it is called homoscedasticity. homoscedasticity is expected to occur in the regression model of the data to be processed. Heteroscedasticity test can be performed using Glejser method by regressing all the independent variables on the absolute value of residual. If there are any influences on independent variable to the absolute value of the residual in the model, it means that a heteroscedasticity problem has occured. Heteroscedastisity symptoms are shown by the regression coefficient of each independent variable to the absolutevalue of the residual. If the probability value is greater than the value of alpha (Sig. > $\alpha$ ), certainly the model does not contain any symptoms Heteroscedastisity (Sulyanto, 2011). The results of the data analysis in 
Table 7 using Method Gejser showed that the value of $\alpha>0.05$ for all values of the independent variables, so that it can be concluded there is no heterocedasticity symptom.

\section{Autocorrelation Test}

The Durbin-Watson test ( $D W$ Test) is a test that is extremely popular to examine whether any problem of autocorrelation of the empirical models estimated

has occured. In the Durbin-Watson test uses the criterias below in order to draw a conclusion:

\begin{tabular}{|l|l|}
\hline DW & CONCLUSION \\
\hline$<d L$ & There is correlation (+) \\
\hline$d L \ldots d U$ & No conclusion \\
\hline$d U \ldots 4-d U$ & No autocorrelation \\
\hline $4-d U \ldots 4-d L$ & No conclusion \\
\hline$>4-d L$ & There is autocorrelation (-) \\
\hline
\end{tabular}

The result of the analysis on the model summary (Table 8) is that the value of Durbin-Watson value amounted as 1.925. The decision making on this assumption requires two auxiliary values obtained from Durbin-Watson Table, which the value of $d L=1.728$ and $d U=1.810$, with $\mathrm{K}=4$ (the number of independent variables) and $n=636$ (the sample size). If the Durbin-Watson value between the value of $d U$ up to 4- $d U$, it means that the assumprion of no autocorrelation occurred has been fulfilled. From the calculations, the value of $D W=1.925$ lies between $d U$ (1.810) and 4-dU (2.190) or it can be conclude that there is no symptoms of the autocorrelation occured.

\section{Hypothesis Testing}

In this research, after the classical assumption test conducted, the hypotheses was being tested and drawed a conclusion that the data were normally distributed and had been free from interference of multicollinearity, heterocedasticity and autocorrelation. The hypothesis testing performed included the Goodness of Fit Test, $F$ test and $t$ test with significance value respectively.

\section{Goodness of Fit Test}

The use of Goodness of Fit Test in this research was to look at the value of R-Square or commonly called the coefficient of determination $\left(R^{2}\right)$. This coefficient showed how much the ability of all the independent variables in explaining the variance of the dependent variable. To calculate the value of the coefficient of determination in this research, figures from adjusted $R^{2}$ were used with the consideration that the value of $R^{2}$ often causes problems, namely that its value will always increase with the addition of independent variables in the model, although the independent variable value does not significantly affect the dependent variable. The calculation in Table 9 showed that the value of adjusted R-square was 0404 . This figure can be interpreted that as much as $40.40 \%$ of the variation in the dependent variable can be explained by the variation of the independent variable, while the remaining $59.60 \%$ is explained by other causes.

\section{Variance Analysis}

Analysis of Variance (ANOVA), usually called the $F$ test, is a test to look for

the level of significance of the overall effect of independent variables towards dependent variable. The calculation results in Table 10 showed that the $F$ calculation value was 108.706 with a significance level of 0.000 . These results were then compared with the value of $F$ table (2.463) with a 0.05 significance. Based on these results it can be 
concluded that the independent variables collectively affected the dependent variable, as a result $F$ calculation was larger than $F$ table (value of $F$ calculation $>F$ table) and the results of the research significance was smaller than 0.05 $(0.000<0.05)$.

\section{T Test}

$T$ test is a test to determine whether each of the variables, namely: $E P S, D E R$, $R O A$ and $R O E$ individually affect the dependent variable of $A E R$.

From the calculation in table 11, by comparing the value of $t$ calculation with $t$ table at the 0.05 two tail significance level valued as 1,984 , then compared with the $t$ value for EPS variable which is equal to 4.317 at 0.05 significance level was 0.000 . The value of $t$ calculation was 4.317 located outside the area of $t$ table between -1.984 and +1.984 , therefore it can be concluded that EPS partial coefficient significantly affect the dependent variable of $A E R$. Similarly to the variables of $D E R, R O A$, and $R O E$ having $\mathrm{t}$ calculation located outside the area of the $t$ table, thus it can be concluded that the variables of $D E R, R O A$ and $R O E$ also significantly affect the dependent variable $A E R$.

\section{Beta Coefficient}

In this research, analysis of the results of the regression calculation was conducted, particularly regarding the value of the beta coefficient, as it has done on previous regression analysis.

The results of regression analysis of conventinal company stock in 2014 2015 using the Fama and French Three Factor Model for positive dividend were:

- The coefficient value of the constant model was -0.057. It showed that in that model, if all the independent variables have a zero value, the dependent variable $A E R$ will generate value as much as -0.057.

- The coefficient value of the variable $E P S$ was 0.000018 . It indicated a positive relation, meaning that each of the increase in value of the independent variable EPS will increase the value of the dependent variable $A E R$ as much as 0.000018 .

- The coefficient value of the variable $D E R$ was 0.007. It indicated a positive relation, meaning that each of the increase in value of the independent variable $D E R$ will increase the value of the independent variable of $A E R$ as much as 0.007 .

- The coefficient value of the variable $R O A$ was 0.003 . It indicated a positive relation, meaning that each of the increase in value of the independent variable $R O A$ will increase the value of the dependent variable $A E R$ as much as 0.003 .

- The coefficient value of the variable $R O E$ was -0.002. It indicated a negative relation, meaning that each of the increase in value of the independent variable $R O E$ will decrease the value of the dependent variable $A E R$ as much as -0.002

\section{Conclusions and Recommendations}

\section{Conclusion of The Research}

The conclusions of this study were based on testing and data analysis as follows:

1). This research resulted in the establishment of 8 stock portfolios, namely:

a). Dividend increase on conventional stock in 2014 using Fama and French

Three Factor Model (see Table 3a).

b). No dividend increase on conventional stock in 2014 using Fama and French Three Factor Model (see Table 3b). 
c). Dividend increase on shari'ah stock in 2014 using Fama and French Three Factor Model (see Table 3c).

d). No dividend increase on shari'ah stock in 2014 using Fama and French Three Factor Model (see Table 3d).

e). Dividend increase on conventional stock in 2015 using Fama and French Three Factor Model (see Table 3e).

f). No dividend increase on conventional stock in 2015 using Fama and French Three Factor Model (see Table 3f).

g). Dividend increase on shari'ah stock in 2015 using Fama and French Three Factor Model (see Table 3g).

h). No dividend increase on shari'ah stock in 2015 using Fama and French Three Factor Model (see Table 3 h).

2). Hypotheses $H_{1}$ until $H_{5}$ were all accepted. From the calculation in table 11, by comparing the value of $t$ calculation with $t$ table at the 0.05 two tail significance level valued as 1.984, then compared with the $t$ value for $E P S$ variable which is equal to 4.317 at 0.05 significance level was 0.000 . The value of $t$ calculation was 4.317 located outside the area of $t$ table between -1.984 and +1.984 , therefore it can be concluded that EPS partial coefficient significantly affect the dependent variable of AER. Similarly to the variables of $D E R, R O A$, and $R O E$ having $\mathrm{t}$ calculation located outside the area of the $t$ Table, thus it can be concluded that the variables of $D E R, R O A$ and $R O E$ also significantly affect the dependent variable $A E R$. Table 10 concluded that the ROA, $E P S, D E R$ and $R O E$ collectively gave positive and significant impact on stock returns in companies listed on the Indonesia Stock Exchange.

3). Hypotheses $\mathrm{H}_{6}$ until $\mathrm{H}_{8}$ were all rejected. The calculation results in Table 11.b concluded that the Beta and $H M L$ variables gave positive influence but not significantly affect the excess return, while the $S M B$ variable gave negative influence but did not significantly affect the excess return.

4). Hyphoteses $\mathrm{H}_{9}$ until $\mathrm{H}_{16}$ were all rejected (see Table 28). So it can be concluded that there was no difference of return before and after the announcement of cash dividends on all types of conventional and shari'ah stock portofolios during 2014 $-2015$.

5). All the formation of the acquired portfolio affirmed that the dividend announcement contains information and market reacted swiftly after finding the dividend announcement (see Table 20 until Table 27). It can be said that the Indonesian capital market conditions have started heading to a semi-strong form.

6). On the formations of portfolios of postive dividend on shari'ah stock in 2014 (figure 3), positive dividend on conventional stock in 2015 (figure 5) and negative dividend on conventinal stock in 2015 (figure 6) seemed a declining graph on day $t-1$ or the day before the announcement date. It was presumed that there was a leak of information on companies using models: Fama and French Three Factor Model before it was announced by the Financial Services Authority (OJK).

6.2. Limitations and Suggestions for the Research

This research was limited to the use of Fama and French Three Factor Model. The only method used was Asset Pricing Model and the sample only used 
two period of times, has not been able to represent the general conclusions. Therefore, it is suggested that the next research can extend the period of times and use more the Asset Pricing Model method.

\section{References}

Agbaje, W.H., Busari, G.A and Adeboye, N.O., 2014, Effects of Accounting Information Management on Profitability of Nigerian Banking Industry, International Journal of Humanities Social Sciences and Education, Volume 1, Issue 9, ISSN: 2349-0381

Akhtar, S and M. Jahromi, 2015, Risk, return and mean-variance efficiency of Islamic and non-Islamic stocks: evidence from a unique Malaysian data set. Accounting and Finance.

Al-Yahyaee, K.H., Pham, T.M and Walter, T.S., 2011, The Information Content of Cash Dividend Announcements in a Unique Environment, Journal of Banking \& Finance 35:606-612.

Ang, Robert, 1997, Buku Pintar Pasar Modal Indonesia. Jakarta: Mediasoft Indonesia.

Apergis, et., all., 2011, Accounting Information and Cost of Capital: A Theoretical Approach, Modern Economy,2, 589-596.

Asiri, B.K., 2014, Dividend Announcement: Is it a Good News to the Bahrain Bourse?, International Journal of Economics and Finance, Vol.6 No.12, ISSN: 19169728.

Ball, R., dan P.Brown, 1968, An Empirical Evaluation of Accounting

Income Numbers. Journal of Accounting Research 6: 159-178.

Binsar I.K.T and Sumiyana, 2008, Event Study: Pengumuman Laba Terhadap Reaksi Pasar Modal (Study Empiris, Bursa Efek Indonesia 2004-2006). Jurnal Manajemen Teori dan Terapan, Tahun.1 No.3
Blanco, B., 2012, The Use of CAPM and Fama and French Three Factor Model: Portfolios Selection, Public and Municipal Finance, Volume 1, Issu 2.

Brown, K.C., Harlow, W.V and Tinic, S.M.,1988, Risk Aversion, Uncertain Information and Market Efficiency, Journal of Financial Economics, 22: 355-385.

Damar Hardianto and Suherman, 2007, Pengujian Fama and French Three Factor

Model di Indonesia”. Jurnal Keuangan dan Perbankan, Vol. 13, No. 2.

Darabi, R., 2012, The Effect of Information Assymmetry on Stock Return Predictability, Research Journal of Applied Sciences, Engineering and Technologi, 5(3):929-936, ISSN:2040-7459

Dharmarathne, D.G., 2013, Stock Price Reaction to Dividend Announcements and Information Efficiency in Sri Lankan Share Market, International Journal of Research in Social Sciences, Vol.3, No.2, ISSN: 2307-227X.

Fama, F.Eugene and French, KR, 1996, Multifactor Explanations of Asset Pricing

Anomalies. Journal of Finance 51(1): 55-84.

1993, Common Risk Factors in the Return on

Stock and Bonds. Journal of Finance Economics: 33: pp. 3-56

The Cross-Section of Expected Stock

Returns. The Journal of Finance. Vol. XLVII.

1998, Value Versus Growth: The International

Evidence. Journal of Finance, Vol. LIII, No.6.

Size and Book-to-Market Factors in 
Earnings and Return. The Journal of Finance, Vol.L No.1

Fitri, R.,R., Hosen, M.,N and Muhari, S., 2016, Analysis of Factors that Impact Dividend Payout Ratio on Listed Companies at Jakarta Islamic Index, International Journal of Academic Research in Accounting, Finance and Management Sciences, Vol.6, No.2, pp.87-97.

Gantyowati, Evi and Sulistyani, 2008, Reaksi Pasar Terhadap Pengumuman

Dividen Pada Persahaan Yang Masuk Corporate Governance Perception Index. Jurnal Bisnis danAkuntansi, Vol.10. No.3

Healy, Paul dan Palepu, K., 2001, Information Asymmetry, Corporate Disclosure and the Capital Markets: A Review of the Empirical Disclosure Literature. Journal of Accounting and Economics 31:405-440

Hermuningsih Sri and Wardani D., Kusumah, 2009, Analisis Reaksi Pasar Modal

Terhadap Peristiwa Right Issue dan Pengumuman Dividen Yang Ditunjukkan Oleh Excess Return. The 3nd National Conference on Mangement Research Bandung 5 Nopember 2009. ISSN: 2086-0390 Hidayati A., Mulia, 2014, Analisis Harga Saham dan Rata-Rata Excess Return

Sebelum dan Sesudah Ex-Dividend Date, Studi Pada Emiten Indeks Kompas 100. Trikonomika, Vol.13 No.1, 2014, ISSN: 1411-514X

Http://www.investopedia.com/terms Husnan, S and Pudjiastuti, 2012, DasarDasar Manajemen Keuangan, Edisi Keenam, UPP STIM YKPN, Yogyakarta.

Indonesia Stock Exchange, 2016, Available at: http//www. idx.co.id

Jogiyanto, H.M., 2003, Teori Portofolio
Dan Analisis Investasi. Edisi 3. BPFE

Yogyakarta

Jogiyanto, H.M.,2015. Studi Peristiwa: Menguji Reaksi Pasar Modal Akibat Suatu

Peristiwa. Edisi Pertama Cetakan Kedua, BPFE Yogyakarta.

Jogiyanto, H.M., 2012, Pasar Efisien Secara Informasi, Operasional dan Keputusan. Edisi Kedua Cetakan Pertama, BPFE Yogyakarta

Kholisoh Luluk dan Agung R, Suryawan, 2007, Pengaruh Pengumuman Dividen

Terhadap Perubahan Harga Saham: Studi di Bursa Efek Jakarta.

Universitas Gunadarma Jakarta, ISSN: 1411-3880

Kyle, A., S., 1985, Continuous Auctions and Insider Trading, Econometrica, Vol.53, No.6, 1315-1336

Manzoor, H., 2015, Impact of Dividends Announcements on Stock Returns Evidence From Karachi Stock Market, American Research Journal of Business and Management, Volume 1, Issue 2, ISSN: 2379-1047.

Medeiros, Otavio R.,De and Matsumoto Alberto S, 2006, Market Reaction to StockIssues in Brazil: Insider Trading, Volatility Effects and the New Issues Puzzle, Investment Management and Finantial Innovations, No.3 Issue 1.

Noori, F., Jalili, $M$ and Nia, H.,S., 2014, The Relationship Between Accounting Information and Stock Volatility, Journal of Novel Applied Sciences, ISSN:2322-5149.

Novak, J., 2008, On the Importance of Accounting Information for Stock Market Efficiency, Dissertation Presented at Uppasala University, ISSN: 1103-8454, ISBN: 978-91506-1983-6

Prayitno Y. Heru., 2012, Excess Return 
di Sekitar Tanggal Pengumuman

Pembagian Dividen Setelah Lama Tidak Membagi: Studi Pristiwa Berbasis Data Intraday. Proceeding Pekan Ilmiah Dosen FEB-UKSW.

Ratnawati, Sumiyati and Triyuwono. Iwan, 2009, Analisa Dampak Pengumuman

Dividen Terhadap Return, Variabilitas Tingkat Keuntungan dan Aktivitas Volume Perdagangan Saham. Wacana, Vol.12 No.4, 2009. ISSN:1411-0199712.

Samsul, Mohammad, 2010, Pasar Modal dan Manajement Portofolio, Jakarta:

Erlangga.

Sudira, P.I.D.G and Ketut,S.I., 2014, Analisis Reaksi Pasar Terhadap Pengumuman

Pengumuman Dividen Tunai Pada Perusahaan Yang Terdaftar di Bursa Efek Indonesia. E-Journal Akuntansi Universitas Udayana, ISSN:2302-8556

Skinner, Douglas, 1994, Why Firms Voluntarily Disclose Bad News. Journal of Accounting Research 32(1): 3861.

Sujana I.K and Yuliantari N.N.A, 2014, Pengaruh Financial Ratio, Firm Size dan

Cash Flow Operating Terhadap Return Share Perusahaan F\&B. e-Jurnal Akuntansi Universitas Udayana. ISSN: $2302-8556$

Sularso, R. A., 2003, Pengaruh Pengumuman Dividen Terhadap Perubahan Harga
Saham Sebelum dan Sesudah ExDevidend Date di Bursa Efek Jakarta (BEJ). Jurnal Akuntansi dan Keuangan: Vol. 5 No. 1.

Sulyanto, 2011, Ekonometrika Terapan: Teori dan Aplikasi dengan SPSS. Penerbit Andi Yogyakarta.

Susanti, N., 2013, Pengujian Fama and French Three Factor Model Pada

Perusahaan di Indonesia Yang Shamnya Terdapat di LQ45 Tahun 20052009. Prosiding Seminar Nasional Forum Keuangan dan Bisnis II. ISSN: 978-602-17225-1-0.

Tandelilin, Eduardus, 2010, Portofolio dan Investasi: Teori dan Aplikasi, Edisi

Pertama. Penerbit Kanisius, Yogyakarta. Uddin, Md.,H and Osman, D., 2008, Effect of Dividend Announcement on Shareholders Value: Evidence From Saudi Arabian Stock Exchange, The International Journal of Business and Finance Research, Volume 2, Number 1,

Ulupui, IGKA, 2005, Analisis Pengaruh Rasio Likuiditas, Leverage, Aktivitas, dan Profitabilitas Terhadap Return Saham (Studi Pada Perusahaan Makanan dan Minuman Dengan Kategori Industri Barang Konsumsi di BEJ). Jurnal Akuntansi, Bali: Universitas Udayana

Yulia I Gusti Ayu and Artini Luh Gede Sri, 2015, Dampak Pengumuman Dividen

Terhadap Excess Return Pada Perusahaan LQ45 Yang Terdaftar Di Bursa Efek Indonesia. E-Jurnal Manajemen Unud, Vol.4 No.12, 2015. ISSN: 2302-8912. 